\title{
İğde (Elaeagnus angustifolia L.)'nin Yetiştiği Toprakların Bazı Fiziksel ve Kimyasal Özellikleri ile Ağır Metal Durumunun Değerlendirilmesi: Erzurum Örneği
}

\author{
Nesrin YILDIZ ${ }^{1 *}$, Murat ZENGIN ${ }^{(D 2}$ \\ ${ }^{1}$ Atatürk Üniversitesi, Ziraat Fakültesi, Erzurum \\ 2Pamukkale Üniversitesi, Mimarlık ve Tasarım Fakültesi, Denizli \\ Geliş Tarihi (Received): 27.06.2019, Kabul Tarihi (Accepted): 08.08.2019 \\ $\square$ Sorumlu Yazar (Corresponding author*): nyildiz@atauni.edu.tr \\ (C. +904422312464 且 +904422315878
}

ÖZ

Bu çalışmasının amacı Erzurum kentinde iğde bitkisinin (Elaeagnus angustifolia L.) yetiştiği 4 lokasyon (Şehir Merkezi, Üniversite, Yenişehir/Yıldızkent yerleşim alanı ve Dadaşkent yerleşim alanı)'da 5 farklı noktadan alınan toprak örneklerinin bazı kimyasal ve fiziksel özellikleri (toprak tekstürü, $\mathrm{pH}, \mathrm{CaCO}_{3}$, organik madde, $\mathrm{KDK}$, değişebilir $\mathrm{K}$ ) ile ekstrakte edilebilir potansiyel toksik ağır metal $(\mathrm{Pb}, \mathrm{Co}, \mathrm{Cd}$ ve Ni) içeriklerini analiz etmektir. Toprak örneklerindeki ağır metal analizleri Atomik Absorbsiyon Spektrofotometre cihazında yapılmıştır. Ölçüm değerlerinin istatistiksel açıdan anlamlılığı Duncan Testi ile belirlenmiştir. Elde edilen verilerin ışığında lokasyonlarda toprakların pH bakımından nötr ile hafif alkali olduğu, kireçlilik bakımından kireçli ve orta kireçli, organik madde içeriği bakımından iyi düzeyde olduğu, katyon değişimi bakımından mevcut kil içeriği ile uyumlu olduğu, değişebilir potasyum açısından fazla ve çok fazla sınıfına girdiği belirlenmiştir. Toprak tekstürü bakımından ise Yenişehir/Yıldızkent toprak örnekleri tınlı iken diğer istasyonlar kumlu tınlı olduğu tespit edilmiştir. Ağır metal değerlerinin izin verilebilir sınır değerler ile karşılaştırıldığında ağır metal içeriklerinin ( $\mathrm{Pb}, \mathrm{Co}, \mathrm{Cd}$ ve $\mathrm{Ni}$ ) kritik değerlerin altında olduğu belirlenmiştir. Lokasyonlara göre topraktaki ağır metal konsantrasyonlarının "ppb" düzeyinde düşük sınırlarda olduğu ve istasyonlardaki topraklarda ağır metallerin ( $\mathrm{Pb}, \mathrm{Co}, \mathrm{Cd}$ ve $\mathrm{Ni}$ ) toksisite riski bulunmadığı belirlenmiştir.

Anahtar Kelimeler: Ağır metaller, iğde, toprak fiziksel ve kimyasal özellik, kirlilik

\section{Evaluation of Some Physical and Chemical Characteristic and Heavy Metal Status of Russian olive (Elaeagnus angustifolia L.)'s Soils: Case of Erzurum Province, Turkey}

\begin{abstract}
This study has the objective of analyzing soil samples taken from 5 different spots in 4 locations in Erzurum Province where Russian olive (Elaegnus angustifolia L.) plant is cultivated (city center, university, Yenişehir/Yıldızkent and Dadaşkent residential area) to assess certain chemical and physical properties (soil texture, $\mathrm{pH}, \mathrm{CaCO}_{3}$, organic substance, KDK, exchangeable $\mathrm{K}$ ) and potential extractable toxic heavy metal ( $\mathrm{Pb}, \mathrm{Co}, \mathrm{Cd}$ and $\mathrm{Ni}$ ). Heavy metal analyses were performed on Atomic Absorption Spectrophotometer device using the soil samples. Statistical significance of the measured value is identified with Duncan Test. The data obtained reveals that the soil is neutral in terms of $\mathrm{pH}$ and slightly alkali; it is calcareous and moderately calcareous in terms of lime; has good levels of organic substances, is in good harmony with clay content in terms of cation exchange, and is classified to have high and very high exchangeable potassium. The samples from Yenişehir/Yıldızkent are loamy and other stations are sandy and
\end{abstract}


loamy. It was found that the heavy metal content $(\mathrm{Pb}, \mathrm{Co}, \mathrm{Cd}, \mathrm{Ni})$ is below critical values when compared with the permissible values of heavy metals. According to locations, heavy metal concentrations in the soil are at low limits at "ppb" level and it was determined that heavy metals $(\mathrm{Pb}, \mathrm{Co}, \mathrm{Cd}$ and $\mathrm{Ni})$ did not have any risk of toxicity in soils.

Keywords: Heavy metals, Russian olive, soil physical and chemical characteristic, pollution

\section{Giriş}

Doğada yaşayan canlı türlerinin doğal yaşam alanlarının kirlenmesine; radyoaktif maddeler, sanayi atıkları, evsel ve kentsel atıklar, doğal kaynakların yanlış ve lüzumsuz kullanımı, plansız kentleşme, endüstrileşme, nükleer faaliyetler ve ağır metaller neden olmaktadır. Kirlenmenin etkisi ile her geçen gün su, hava ve toprakta biriken toksik elementler doğal yaşamı tehdit etmektedir. Doğada ağır metal kirliliğine; yoğun tarımsal faaliyetler, pestisitler, kimyasal gübreler, sanayileşme, maden yatakları, maden işleme tesisleri, volkanik faaliyetler, termik santrallerin bacalarından çıkan uçucu küller, çimento fabrikaları, havayolu, demiryolu, karayolu araçları tarafından salınan gazlar, ağır metal içerikli boyalar, atık çamur yakma tesisleri, endüstri atıklarının rastgele doğaya atıması gibi etmenler sebep olmaktadır. Gün geçtikçe küçük partiküller halinde ya da çözünmüş olarak toprağa geçen ağır metaller başta hareket etme yeteneği olmayan bitkilerde toksisiteye neden olarak verim ve kalite kayıplarına yol açmakta ve bitkilerle beslenen canlı hayatını tehdit etmektedir (Dean ve ark., 1972; Robert, 1995; Lombardo ve ark., 2001).

Son yıllarda, yüksek bitkilerde kadmiyum (Cd), krom $(\mathrm{Cr})$, kurşun $(\mathrm{Pb})$ ve cıva $(\mathrm{Hg})$ gibi ağır metallerin varlığına iliş̧in çok sayıda rapor edilen araştırma bulgularına rastlanmaktadır. Bu raporların çoğu esas olarak özellikle çevre kirliliğine işaret eden çalışmalarla ile ilgilidir. Besin zincirinde ağır metallerin kritik toksisite seviyelerinin, bitkilerde genotipik farklılıklara neden olabilecek düzeyde sorunlara neden olacak boyutta sakıncalı olduğunu belirten raporlar da bu araştırmalar arasında yer almıştır (Marschner, 1986). Doğa; artan dünya nüfusuna bağlı olarak gün geçtikçe kirlenmektedir. Bilim dünyası kirlenmenin etkisini azaltmak ve giderilmesine yönelik çalışmalar üzerine yoğunlaşmıştır. Kirlenmiş toprak ve su kaynaklarının iyileştirilmesinde, biyoremediasyon, fitoremediasyon, fiziksel ve kimyasal teknikler çok yoğun bir şekilde kullanılmaktadır (Khan, 2003).

Ağır metaller; kurşun, kadmiyum, krom, demir, nikel, çinko ve civa da dahil olmak üzere 60 'tan fazla metallik özellik gösteren ve yeryüzünde doğal olarak bulunmaları nedeniyle yok edilemeyen, bitkiler, hayvanlar ve insanlar için toksik etkileri olan elementlerdir. Bitki doku ve organlarında aşırı birikimi üzerine yapılan çalışmalar güçlü fitotoksik maddeler olduğunu, büyümeyi engellediğini ve hatta bazı durumlarda bitkinin tamamen ölümüne neden olduğunu ortaya koymuştur (Prasad, 1995; Salt, 2001).
Mattigod ve Page (1983) bitkiler için toksik etkiye sahip ağır metallerden; krom, nikel ve kurşunun topraklarda 10 - 100 ppm arasında, kadmiyumun ise 1 ppm in altında bulunması gerektiğini ve bu miktarların normal seviyeler olarak kabul edilebileceğine, bu miktarların üzerine çıkılması durumunda bitki ve insan sağlığı açısından ağır metallerin olumsuz etkileri olabileceğine işaret etmişlerdir

Herrick ve Freidlve (1990) tarafından bitkiler ve canlılar için toksik olan bazı ağır metallerin topraktaki izin verilebilir sınır değerlerin; nikel için 10-50 ppm, Co için 1-20 ppm, Cr içinde 10-80 ppm arasında olması gerektiği belirtilmiştir. Bu değerlerin üzerinde olması durumunda bitkilerde toksisite gözlemlenebileceğini ve bitkiden bitkiye ağır metallerin toksik belirtilerinin değişebileceğini ifade etmişlerdir.

Fitoremediasyon yöntemiyle topraktan kirleticilerin uzaklaştırılması için kullanılacak bitkileri tespit etmek amacıyla pek çok araştırma yapılmıştır. Araştırmalar sonucunda bünyesinde ağır metalleri biriktirebilen 45 bitki familyası tespit edilmiştir. Bu bitkiler $\mathrm{Cu}, \mathrm{Co}, \mathrm{Cd}, \mathrm{Mn}, \mathrm{Ni}$, Se ve $\mathrm{Zn}$ gibi metalleri bünyelerinde $100-1000$ ppm seviyesinde biriktirebildiği ifade edilmiştir (Reeves ve Brooks, 1983). Topraklardan ayrıştırılabilir ağır metal miktarları; kadmiyum (Cd) için $1 \mathrm{mg} / \mathrm{kg}$, kobalt (Co) için 10 $\mathrm{mg} / \mathrm{kg}$, bakır $(\mathrm{Cu})$ için $0,1 \mathrm{mg} / \mathrm{kg}$, selenyum (Se) için 10 $\mathrm{mg} / \mathrm{kg}$, vanadyum $(\mathrm{V})$ için $0,5-1 \mathrm{mg} / \mathrm{kg}$, nikel (Ni) için 100 $\mathrm{mg} / \mathrm{kg}$ in üzerinde olduğu durumlarda bitkiler için toksik etkilerinin görülebileceği bildirilmiştir (Kabata - Pendias ve Pendias, 1989; Yıldız, 2001).

Tarımsal ekosisteme bir şekilde dahil olan $\mathrm{Cd}, \mathrm{Cr}, \mathrm{Hg}$ ve $\mathrm{Pb}$ gibi ağır metaller biyolojik döngüye de girmektedir. Konsantrasyonlarına ve hareketlilik düzeyine bağlı olarak toprakta bitkilerce alınabilir veya bitki bünyesinde depolanabilirler. İnsan sağlığı açısından meyve ve sebzelerde $\mathrm{Hg}$ ve Cd'un kritik düzeyleri 0.05 ppm'in altındadır (Haktanır ve Arcak, 1998). Ni, Cr, Pb, Hg, Cd ve As gerekli elementler değildirler. Çoğu ağır metal bir diğerine benzer olabildiğinden karakteristik semptomlara sebep olurlar (Patterson, 1971).

Trafik yoğunluğu ve egzoza bağlı metal kirliliğinde Pb'nin yanı sıra, motor yağlarında ve oto lastiklerinde katkı maddesi olarak kullanılan $\mathrm{Cd}$, motor alaşımlarının aşınmasından ortaya çıkan $\mathrm{Cu}$ ve $\mathrm{Ni}$, taşıtlardan kaynaklanan ağır metal kirliliğinin ana unsurlarıdır (Bilge ve 
Çimrin, 2013). Ağır metaller genel olarak endüstriyel emisyonlardan, ısıtmada kullanılan fosil yakıtlardan ve araçların egzozlarından havaya salınır (Önder ve ark., 2007). Topraklara karışan kadmiyumun (Cd) \%5458 'inin fosforlu gübrelerden, \%39-47'sinin atmosferden ve \%2-5'nin kanalizasyon atıklarının kullanımından kaynaklandığı bildirilmektedir (Alloway, 1995). Kabata-Pendias ve Pendias (1984), topraklarda Cd değerleri için 0.02-4 ppm, Cr için 0.1-1 ppm, Co için 0.5-6.5 ppm, Pb için 2-300 ppm, Ni için 2-750 ppm'in normal seviyeler olduğunu kabul etmektedirler.

Bayar (2009) yaptığı çalışmada, Erzurum İli Şehir merkezinde trafik ve hava kirliliğinin yoğun olduğu 11 ayrı noktadan Ağustos ayında toprak, Ocak ve Ağustos aylarında bitki (Pinus sylvesteris L.) örneği alınarak ağır metal kirliliği araştırmıştır. Örnekleme noktalarından alınan toprakların ve bitkilerin ağır metal içerikleri gerek noktalar arasında ve gerekse dönemler arasında önemli düzeyde $(p<0.001)$ farklılık göstermiştir. Toprak örneklerinin ağır metal içerikleri, 100. Yıl Parkı'nda Fe, Cu ve Zn normal sınırın üzerinde bulunmuş olup, diğer kavşaklarda bütün ağır metaller normal sınırın altında bulunmuştur. Sarıçam yüzeyine bulaşan ağır metaller dahil (yıkanmadan analize alınan) bitki örneklerinin ağır metal içerikleri incelendiğinde; Fe metali tüm örnekleme yerlerinde (kavşaklarda) Ağustos ve Ocak ayında; Cu metali Ağustos ve Ocak ayında İstasyon (Migros) kavşağında; Zn metali Ocak ayında Havuzbaşı -Üniversite kavşağı arasında; Pb metali Ocak ayında Migros kavşağında; Ni metali Ocak ayında Günsazak (Yenişehir) kavşağında toksik düzeyde bulunmuştur.

Bilge ve Çimrin (2013) Mardin Viranşehir-Kızıltepe karayolu güzergahındaki topraklarda ağır metal trafik kay- naklı ağır metal kirliliğinin boyutlarını belirlemek ve topraktaki ağır metal miktarının kara yolundan olan mesafe ile değişimini ortaya koymak amacıyla karayolunun sağ ve sol tarafından ikişer km'lik 6 farklı noktadan 0, 15, 30 ve $60 \mathrm{~m}$ uzaklıklarla $0-15 \mathrm{~cm}$ derinlikte 4 tekerrürlü toprak örneği almışlardır. Sonuç olarak toprakların ortalama ağır metal içerikleri $\mathrm{Pb}$;0.64-2.24 ppm, Cd;0.26-0.40 ppm, Ni; 27-42 ppm, Cr;17-28 ppm, Cu;9.9-14.2 ppm olarak belirlemişlerdir. Bulgular göstermiştir ki, elde edilen sonuçları izin verilebilir sınır değerlere yaklaşmasa da, karayolundan uzaklaştıkça ağır metal konsantrasyonu azalmıştır.

\section{MATERYAL VE YÖNTEM}

Genel olarak Erzurum kenti ilkim ve toprak şartlarında yetişebilen iğde (Elaeagnus angustifolia L.) bitkisine ait toprak örnekleri ana materyali oluşturmaktadır. Özellikle trafik yoğunluğunun fazla olduğu ana ulaşım yolları, orta refüjler ve yola yakın (0-20 m.) alanlardaki toprak örnekleri, bitki kök derinliği temeline göre alınmıştır. Toprak örnekleri; (a) ana ulaşım yolları (anayol, kaldııım ve orta refüjler), (b) anayola çok yakın (arsa, park veya bahçeler) ve (c) bitkinin anayola bakan tarafından toplanmıştır. Erzurum kent dokusu içerisinde kent genelini yansıtabilmesi açısından örnekleme noktaları olarak; (1) Şehir Merkezi, (2) Üniversite Yerleşkesi, (3) Yenişehir ve Yıldızkent yerleşim alanı ve (4) Dadaşkent yerleşim alanı olmak üzere 4 lokasyon seçilmiştir (Şekil 1). Her istasyonda yaklaşık olarak 5 ile 10 yaş aralığında değişen iğde (Elaeagnus angustifolia L) bitkisinin yetiştiği toprak örnekleri usulüne uygun bir şekilde her lokasyondan kök derinliği temel alınarak 5 alt örnek alınıp bez torbalara konularak numaralandırılmıştır.

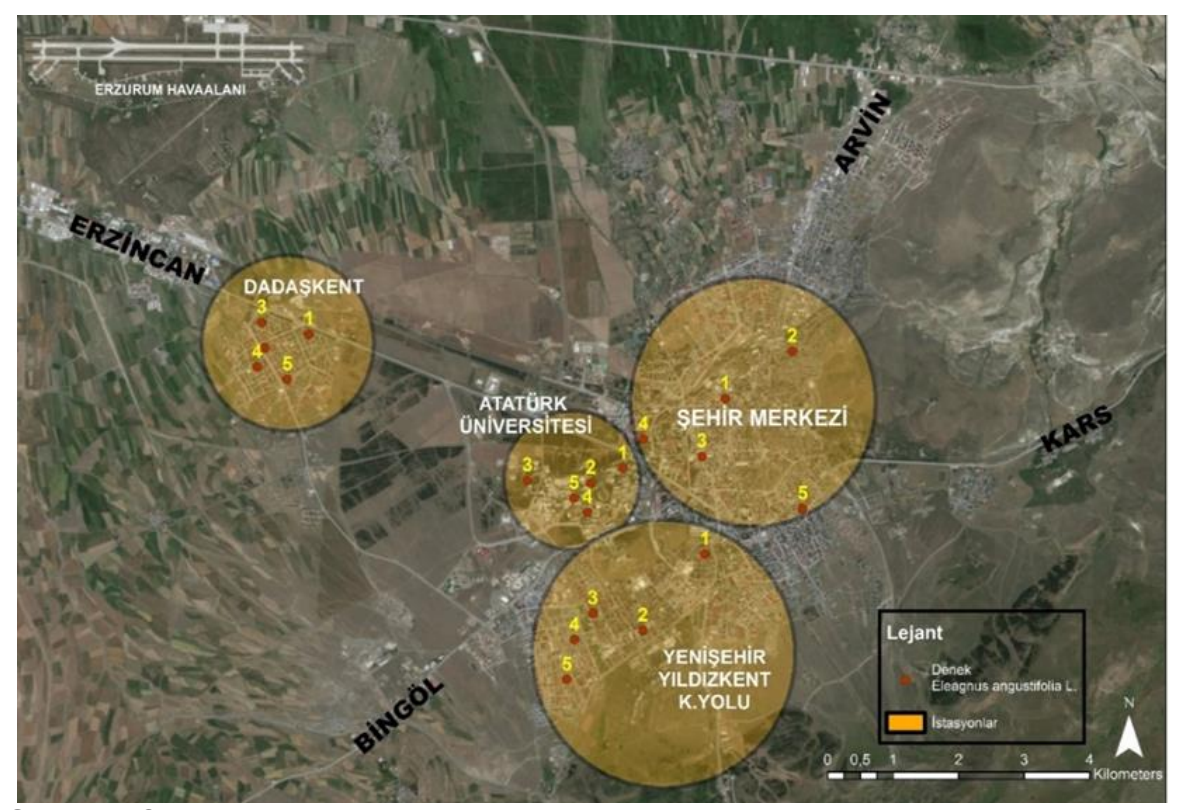

Şekil 1. Çalışma alanı lokasyonları ve toprak örneklerinin toplandığı noktalar 
Söz konusu lokasyonlardan usulüne uygun bir şekilde alınan toprak örnekleri laboratuvarda hava kurusu haline getirilip, $2 \mathrm{~mm}$.'lik elekten geçirilerek analize hazırlanmıştır. Dört farklı noktadan toplanan toprak örneklerinin bazı fiziksel ve kimyasal özellikleri (toprak tekstürü, $\mathrm{pH}$, $\mathrm{CaCO}_{3}$, Organik madde, $\mathrm{KDK}$, değişebilir $\mathrm{K}$ ) ve ekstraksiyon çözeltilerinde potansiyel toksik ağır metal $(\mathrm{Pb}, \mathrm{Co}$, $\mathrm{Cd}$ ve $\mathrm{Ni}$ ) analizleri Atatürk Üniversitesi Ziraat Fakültesi Toprak Bilim ve Bitki Besleme Bölümü Laboratuvarında gerçekleştirilmiştir. Analizlerde kullanılan yöntemler; a) Toprak örneklerinde tekstür analizi hidrometrik yöntemle (Bouyoucos, 1951), b) toprak reaksiyonu 1:2.5 toprak-su solüsyonunda $(\mathrm{pH})$ cam elektrotlu $\mathrm{pH}$ metre ile (Jackson, 1967), c) kireç yüzdesi $\left(\% \mathrm{CaCO}_{3}\right)$ Scheibler kalsimetresi ile (Schlichting ve Blume, 1966), d) katyon değişimi kapasitesi toprağın $\mathrm{NaOAC}$ ile doyurulup, $\mathrm{NH}_{4} \mathrm{OAC}$ ile ekstraksiyon yöntemi ile Değişebilir $\mathrm{Na}^{+}, \mathrm{Ca}^{+2}, \mathrm{Mg}^{+2}$, $\mathrm{K}^{+}, \mathrm{NH}_{4} \mathrm{OAC}$ ile flame fotometrede ölçülmesi ile (Jackson, 1967), e) toprak çözeltisindeki potansiyel $\mathrm{Pb}, \mathrm{Co}$, $\mathrm{Cd}$ ve $\mathrm{Ni}$, DTPA-TEA ekstraksiyonu ile (Lindsay ve Norwell, 1978) atomik absorpsiyon spektrofotometrede okunarak belirlenmiştir. Erzurum kent genelinde iğde (Elaeagnus angustifolia L.) bitkisinin yetişme ortamından alınan toprak örnekleri analizlerine bağlı olarak, istasyonlar bazında fiziksel ve kimyasal özellikleri $\mathrm{pH}$, $\mathrm{CaCO}_{3}$, Organik Madde, $\mathrm{KDK}$ ve $\mathrm{K}$ değişebilir katyonları ve ağır metal konsantrasyon değerleri için istatistiksel analizler yapılmıştır. Analizler neticesinde elde edilen değerlerin istasyonlar bazında normal dağılım gösterip göstermedikleri kontrol edilmiştir. Bağımsız grup farklıIıklarının karşılaştırımasında Tek Yönlü Varyans Analizlerinden Duncan Testi uygulanmıştır. Verilerin normal dağılıma uygun olup olmadıkları Kolmogorov-Smirnov analiz yöntemi ile test edilmiştir. Analizlerde istatistiksel anlamlılık düzeyi $p<0.05$ anlamlı olarak kabul edilmiştir

\section{BULGULAR ve TARTIŞMA}

Yapılan analizler sonucunda iğde (Elaeagnus angustifolia L.) bitkisinin topraklarından alınan örneklerinin $\mathrm{pH}$ değerleri 7.03 ile 7.7 arasında, kireç $\left(\mathrm{CaCO}_{3}\right)$ içerikleri \% 0.32 ile 5.25 arasında, toprak organik madde içerikleri \% 1.09 ile 6.22 arasında, katyon değişim kapasiteleri (KDK) 21.4 ile $39.5 \mathrm{me} \mathrm{/100} \mathrm{g} \mathrm{arasında,} \mathrm{değişebilir} \mathrm{po-}$ tasyum $(\mathrm{K})$ içeriklerinin ise 0.94 ile $3.76 \mathrm{me} / 100 \mathrm{~g}$ toprak arasında değişmekte olduğu tespit edilmiştir. Toprak örneklerine ait bazı fiziksel ve kimyasal analiz sonuçları Tablo 1'de verilmiştir.

Toprak örneklerinin çözeltiye geçen $\mathrm{Pb}, \mathrm{Co}, \mathrm{Cd}$, ve $\mathrm{Ni}$ değerleri sırasıyla; $\mathrm{Pb}, 1.32$ ile $22.11 \mathrm{ppb}$, Co $5.53 \mathrm{ppb}$ ile $566.4 \mathrm{ppb}, \mathrm{Cd} 0.06$ ile $8.41 \mathrm{ppb}$ ve Ni $32.8 \mathrm{ppb}$ ile 918.4 ppb arasında değişmekte olup (Tablo 2) toprakta bitki köküne geçme riski olabilecek düzeyleri ve sınır değerler dikkate alındığında bütün konsantrasyon değerleri izin verilebilir kritik değerlerin çok altında olduğu için potansiyel risk değerlendirmesi açısından sorun teşkil etmemektedir. Nitekim toprak için gerek Kabata Pendias ve Pendias (1984) kritik değerlerin (Cd:0.02-4 ppm, Cr: 0.1-1 ppm, Co: 0.5-6.5 ppm, Pb:2-300 ppm, Ni: 2-750 ppm) gerekse Mattigod ve Page (1983) ve Herrick ve Freidlve (1990) öngörülerine göre normal sınırlardadır. Nitekim bu çalışma kapsamında lokasyonlara göre topraktaki ağır metal konsantrasyonlarının "ppb" düzeyinde ele alındığı dikkate alınacak olursa, değerlerin oldukça düşük sınırlarda olduğu görülmüştür.

Tablo 1. Toprak örneklerinin bazı fiziksel ve kimyasal özelliklerine ilişkin analiz sonuçları

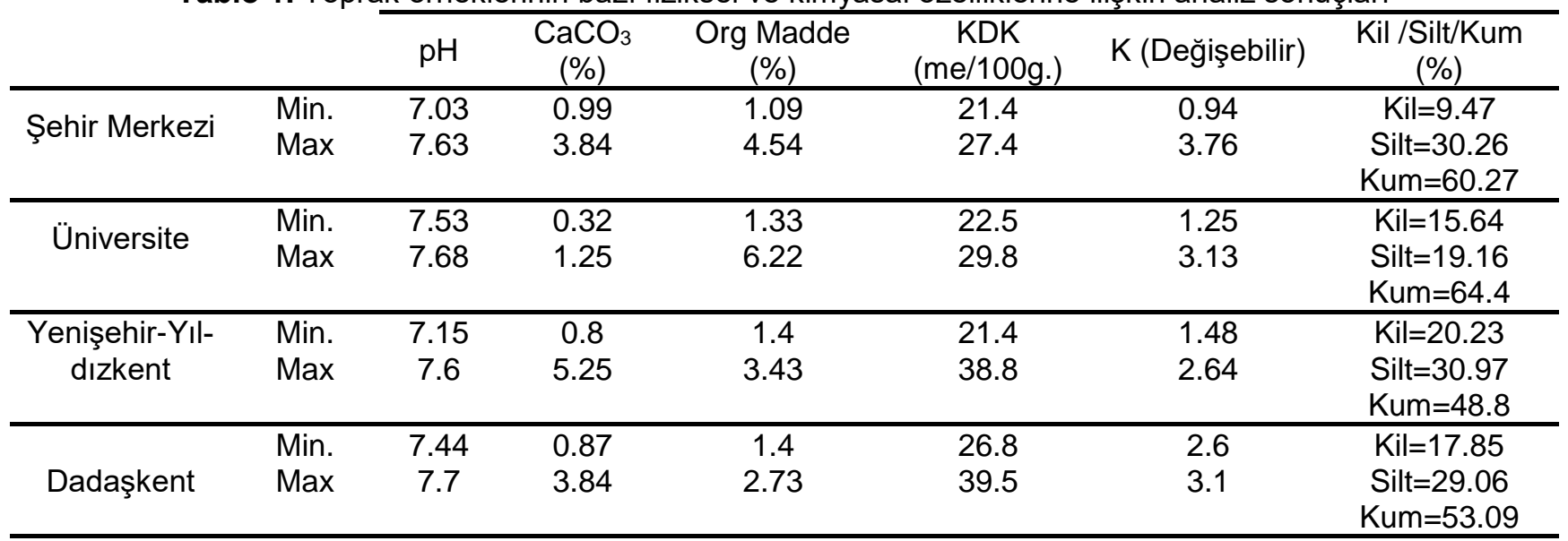


İğde (Elaeagnus angustifolia L.)'nin Yetiştiği Toprakların Bazı Fiziksel ve Kimyasal Özellikleri ile Ağır Metal Durumunun Değerlendirilmesi: Erzurum Örneği

Tablo 2. Toprak örneklerinin ağır metal ( $\mathrm{Pb}, \mathrm{Co}, \mathrm{Cd}$ ve $\mathrm{Ni}$ ) analiz sonuçları (ppb)

\begin{tabular}{lccccc}
\hline İstasyonlar & Ölç. Değ. & $\mathbf{P b}$ & $\mathbf{C o}$ & $\mathbf{C d}$ & $\mathbf{N i}$ \\
\hline \multirow{3}{*}{ Şehir Merkezi } & Min. & 1.32 & 11.71 & 0.81 & 121.88 \\
& Max. & 8.03 & 33.69 & 8.41 & 299.96 \\
\hline \multirow{2}{*}{ Üniversite } & Min. & 1.76 & 5.53 & 2.80 & 260.00 \\
\hline \multirow{2}{*}{ Yenişehir-Yıldızkent } & Max. & 22.11 & 293.32 & 6.40 & 859.60 \\
\hline \multirow{2}{*}{ Dadaşkent } & Min. & 2.99 & 36.19 & 0.44 & 32.80 \\
& Max. & 12.28 & 566.40 & 6.56 & 623.20 \\
\hline
\end{tabular}

Ölçüm değerlerine bağlı olarak Duncan Testi analiz sonuçlarına göre, toprak örneklerinin bazı fiziksel ve kimyasal özelliklerine ilişkin analizler Tablo 3'de, ağır metal elementleri ( $\mathrm{Pb}, \mathrm{Co}, \mathrm{Cd}, \mathrm{Ni})$ ortalamaları ve standart sapmaları ile çoklu karşılaştırma test sonuçları ise Tablo 4'de verilmiştir.

Tablo 3. Toprak örneklerinin bazı fiziksel ve kimyasal özelliklerine ilişkin istatistik analizleri

\begin{tabular}{cccccc} 
& Şehir Merkezi & Üniversite & Yenişehir-Yıldızkent & Dadaşkent & P(sig.) \\
\hline $\mathrm{pH}$ & $7.46^{\mathrm{ab}} \pm 0.25$ & $7.62^{\mathrm{a}} \pm 0.06$ & $7.32^{\mathrm{b}} \pm 0.18$ & $7.58^{\mathrm{a}} \pm 0.09$ & $0.043^{*}$ \\
\hline $\mathrm{CaCO}_{3}$ & $2.68^{\mathrm{a}} \pm 1.12$ & $0.63^{\mathrm{b}} \pm 0.40$ & $3.06^{\mathrm{a}} \pm 1.72$ & $2.70^{\mathrm{a}} \pm 1.18$ & $0.021^{*}$ \\
\hline Org.M & $3.47^{\mathrm{a}} \pm 1.47$ & $3.45^{\mathrm{a}} \pm 1.78$ & $2.59^{\mathrm{a}} \pm 0.79$ & $2.29^{\mathrm{a}} \pm 0.53$ & $0.355^{\text {ös }}$ \\
\hline $\mathrm{KDK}$ & $24.88^{\mathrm{b}} \pm 2.38$ & $25.9^{\mathrm{ab}} \pm 2.90$ & $27.38^{\mathrm{ab}} \pm 6.95$ & $32.3^{\mathrm{a}} \pm 5.07$ & $0.101^{\text {ös }}$ \\
\hline $\mathrm{K}$ & $2.49^{\mathrm{a}} \pm 1.30$ & $1.972^{\mathrm{a}} \pm 0.74$ & $1.97^{\mathrm{a}} \pm 0.56$ & $2.88^{\mathrm{a}} \pm 0.19$ & $0.246^{\text {ös }}$ \\
\hline
\end{tabular}

*: $\mathrm{P}<0.05$, ös: $\mathrm{P}>0.05$ önemsiz (non-sig.); $\mathrm{a}, \mathrm{b}$ ve c: aynı harfle gösterilenler ortalamalar arasındaki fark anlamlı değil, farklı harfle gösterilen ortalamalar arasındaki fark anlamlıdır, $\bar{x} \pm S_{\mathrm{x}}$ ortalama ve standart sapma.

Tablo 4. İstasyonlar bazında ağır metal elementleri $(\mathrm{Pb}, \mathrm{Co}, \mathrm{Cd}, \mathrm{Ni})$ ortalamaları ve standart sapmaları ile çoklu karşılaştırma istatistik test sonuçları

\begin{tabular}{|c|c|c|c|c|c|}
\hline & $\begin{array}{c}\text { Şehir Merkezi } \\
\bar{x} \pm S_{x} \\
\end{array}$ & $\begin{array}{c}\text { Üniversite } \\
\bar{x} \pm S_{x}\end{array}$ & $\begin{array}{c}\text { Yenişehir-Yıldızkent } \\
\bar{x} \pm \mathrm{S}_{\mathrm{X}}\end{array}$ & $\begin{array}{c}\text { Dadaşkent } \\
\bar{x} \pm S_{x}\end{array}$ & $\mathrm{P}$ (sig.) \\
\hline $\mathrm{Pb}$ & $5.14^{\mathrm{a}} \pm 2.43$ & $8.59^{\mathrm{a}} \pm 7.95$ & $7.83^{\mathrm{a}} \pm 3.9$ & $5.87^{\mathrm{a}} \pm 3.27$ & $0.654^{\text {ös }}$ \\
\hline Co & $20.6^{\mathrm{a}} \pm 10.85$ & $145.16^{\mathrm{a}} \pm 105.27$ & $150.26^{\mathrm{a}} \pm 232.75$ & $30.04^{a} \pm 11.9$ & $0.245^{\circ \mathrm{s}}$ \\
\hline $\mathrm{Cd}$ & $2.82^{b} \pm 3.22$ & $5.06^{\mathrm{a}} \pm 1.38$ & $1.97^{b} \pm 2.58$ & $0.82^{b} \pm 0.89$ & $0.049^{*}$ \\
\hline $\mathrm{Ni}$ & $234.95^{\mathrm{a}} \pm 75.0$ & $527.36^{a} \pm 267.08$ & $195.75^{a} \pm 242.29$ & $308.24^{a} \pm 344.32$ & $0.202^{\mathrm{og}}$ \\
\hline
\end{tabular}

Toprak Kirlilik Yönetmeliği ve toprak pH değerleri ile karşılaştırma yapıldığında (Tablo 5), toprak pH'sının nötr veya hafif alkalin olması yönüyle toprak kirlilik yönetmeliğine göre de topraklarda söz konusu ağır metallerin toksisite riski söz konusu değildir. 
Tablo 5. Topraktaki Ağır Metal Sınır Değerleri (Anonim, 2005)

\begin{tabular}{|l|c|c|}
\hline Ağır Metal (Toplam) & PH 5- 6 mg/kg Fırın Kuru Toprak & pH>6 mg/kg Fırın Kuru Toprak \\
\hline Kurşun $(\mathrm{Pb})$ & $50 * *$ & $300 * *$ \\
\hline Kadmiyum $(\mathrm{Cd})$ & $1 * *$ & $3 * *$ \\
\hline Krom $(\mathrm{Cr})$ & $100 * *$ & $100 * *$ \\
\hline Bakır $^{*}(\mathrm{Cu})$ & $50 * *$ & $140 * *$ \\
\hline Nikel $^{*}(\mathrm{Ni})$ & $30 * *$ & $75 * *$ \\
\hline Çinko* $(\mathrm{Zn})$ & $150 * *$ & $300 * *$ \\
\hline Civa $(\mathrm{Hg})$ & $1 * *$ & $1.5 * *$ \\
\hline
\end{tabular}

* pH değeri 7'den büyük ise çevre ve insan sağlığına özellikle yer altı suyuna zararlı olmadığı durumlarda Bakanlık sınır değerleri \%50'ye kadar artırabilir. ** Yem bitkileri yetiştirilen alanlarda çevre ve insan sağlığına zararlı olmadığı bilimsel çalışmalarla kanıtlandığı durumlarda, bu sinir değerlerin aşılmasına izin verilebilir.

Yapılan istatistik analizlerine göre, toprakların $\mathrm{pH}$ ve kireçlilik $\left(\mathrm{CaCO}_{3}\right)$ değerlerinde $\mathrm{P}>0.05$ düzeyinde fark anlamlı iken, organik madde (Org.Mad.), katyon değişim kapasitesi (KDK) ve potasyum (K) değerlerinde farklılık anlamlı bulunmamıştır. Üniversite ve Dadaşkent toprakları pH'sı ile Şehir Merkezi ve Yenişehir/Yıldızkent lokasyonlarının toprak pH'sı değerleri arasındaki fark anlamlı olarak tespit edilmiştir.

Kireçlilik $\left(\mathrm{CaCO}_{3}\right)$ bakımından ise Üniversite lokasyonu ile diğer istasyonların ortalamaları arasındaki fark anlamlı olduğu tespit edilmiştir. Kireç içeriği üniversite topraklarında diğer lokasyonlardan farklı olarak daha düşük bulunmuştur. pH değerleri bakımından Yenişehir/Yıldızkent, Kireçlilik bakımından Üniversite, organik madde bakımından Dadaşkent, katyon değişim katsayısı bakımından Şehir Merkezi, potasyum bakımından Üniversite ve Yenişehir/Yıldızkent lokasyonları ortalamaları en düşük değere sahip yerler olarak tespit edilmiştir. Organik madde içeriği şehir merkezi ve üniversite lokasyonlarında diğer lokasyonlara göre ortalamaları yüksek olduğu bulunmuştur. Ağır metal değerlerinin Duncan test sonuçlarına göre, Üniversite lokasyonundaki topraklarda $\mathrm{Cd}$ elementi içim $\mathrm{P}>0.049$ düzeyinde anlamlı farklılık tespit edilmiştir. $\mathrm{Pb}$, Co ve Ni elementleri için lokasyonlar bazında önemli bir farklılık tespit edilememiştir.

\section{SONUÇ VE ÖNERILER}

Toprakların bitki köküne geçebilme potansiyeli yüksek (ayrıştırılabilir, çözünebilir) ağır metallerin (Pb, Co, Cd ve $\mathrm{Ni}$ ) konsantrasyonları ve toprakların bazı fiziksel ve kimyasal özellikleri ile olası etkileşimleri dikkate alındığında, araştırma konusu toprak örneklerinin kireç $\left(\mathrm{CaCO}_{3}\right)$, kil ve organik madde içeriklerinin iyi seviyede olması, DTPA-TEA (Lindsay ve Norvel, 1978) çözeltisi ile ekstrakte edilen ağır metal konsantrasyonlarının ppb düzeyinde ölçülen seviyelerinin kritik (sınır) değerin çok altında olması yönüyle söz konusu bitkilere olası potansiyel toksik risk teşkil etmesi, mevcut araştırma koşullarında mümkün gözükmemektedir. Bilindiği gibi toprak özelliklerinden kireç, kil ve organik madde (humus) ağır metal riskini tolere etmede topraklar için en temel tamponlayıcı ve koruyucu unsurlardır (Topbaş ve ark.,1998).

Erzurum kentinde istasyonlar bazında iğde bitkisinin toprak örneklerinden elde edilen sonuçlara göre, toprak örneklerinin pH'ları 7.03 ile 7.7 arasında değişmekte olup nötr ile hafif alkalin arasındadır. Toprak örneklerinin kireç $\left(\mathrm{CaCO}_{3}\right)$ içerikleri \% 0.32 ile 5.25 arasında olup az kireçli ile orta kireçli arasındadır. Toprak organik madde içerikleri \% 1.09 ile 6.22 arasında olup, genel olarak memnuniyet verici düzeydedir. Katyon değişim kapasiteleri (KDK) 21.4 ile $39.5 \mathrm{me} / 100 \mathrm{~g}$ arasında değişmekte olup toprakların kil içerikleri ile uyumlu bir durumdadır. Toprak örneklerinin değişebilir potasyum $(\mathrm{K})$ içerikleri 0.94 ile $3.76 \mathrm{me} / 100 \mathrm{~g}$ toprak arasında değişmekte olup, fazla ve çok fazla sınıfına girmektedir, Toprak tekstürü bakımından şehir merkezi, üniversite ve Dadaşkent lokasyonu toprak örnekleri kumlu tınlı iken, Yenişehir/Yıldızkent toprak örnekleri tınlı'dır.

Çalışma kapsamında lokasyonlara göre topraktaki ağır metal konsantrasyonlarının "ppb" düzeyinde düşük sınırlarda olduğu ve istasyonlardaki topraklarda ağır metallerin $(\mathrm{Pb}, \mathrm{Co}, \mathrm{Cd}$ ve $\mathrm{Ni})$ toksisite riski bulunmadığı belirlenmiştir. $\mathrm{Pb}, \mathrm{Cd}$ ve Ni elementi bakımından Üniversite lokasyonu diğer lokasyonlara göre en yüksek değere sahip olduğu tespit edilmiştir. Co elementi Şehir Merkezinde, Cd elementi Dadaşkent'de ve Ni elementi Yenişehir/Yıldızkent lokasyonlarında en düşük değerlere sahip olduğu belirlenmiştir.

\section{KAYNAKLAR}

Alloway, B.J. (1995). Heavy Metals in Soils. Blackie Academic and Professional, Chapman and Hall, London, 368 p. https://doi.org/10.1007/978-94-011-1344-1

Anonim, (2005). Toprak Kirliliğinin Kontrolü Yönetmeliği. Bakanlık: Çevre ve Orman Bakanlığını, Kanun: 31/8/1983 tarihli ve 18132 sayılı Resmi Gazete

Bayar, E. (2009). Erzurum şehir merkezindeki bazı kavşaklarda bitki (Pinus sylvestris) ve toprakların ağır metal (Fe, 
$\mathrm{Cu}, \mathrm{Zn}, \mathrm{Mn}, \mathrm{Cd}, \mathrm{Pb}$ ve $\mathrm{Ni}$ ) kontaminasyon durumunun belirlenmesi, Atatürk Üniversitesi. Fen Bil. Enst., Toprak Anabilim Dalı, Yüksek Lisans Tezi.

Bilge, U., Çimrin, K.M. (2013). Viranşehir -Kızıltepe karayolu kenarındaki topraklarda motorlu taşıtlardan kaynaklanan ağır metal kirliliği, Tarım Bilimleri Dergisi, 19 (4):323-329.

Bouyoucos, G.J. (1951). A Recalibration of hydrometer for marking mechanical analysis of soil, Agronomy Journal, 43; 434-438.

Dean, J.G., Bosqui, F.L., Lanouette V.H. (1972). Removing heavy metals from waste water: Environmental Science and Technology, 6, 518-522.

Haktanır, K., Arcak, S. (1998). Çevre Kirliliği. Ankara Üniversitesi. Ziraat Fakültesi, Ziraat Fak. Yay. No.1503, Ders kitabı: 457.

Herrick, G., Freidl, T. (1990). Patternsoftrace metal concentrationand acidity in mointain forest soils of northeastern US, Water-Air-Soil Pollution, 53, 151-157.

Jackson, M.L. (1967). Soil chemical analysis, Prentice-Hall of India Private Limited, 498p, NewDelhi.

Kabata-Pendias A., Pendias H. (1984). Trace elements in soils and plants, 1st ed. CRC Press, Boca Raton, Florida, USA.

Kabata-Pendias, A., Pendias, H. (1989). Trace elements in the soil and plants. CRC Press, Boca Raton, FL

Khan, A.G. (2003). Vetiver grass as an Ideal phytosymbiont for glomalian fungi for ecological restoration of heavy metal contaminated derelict land. Proceedings of Third Internatioal Vetiver Conference (ICV-3), Guangzhou, China.

Lindsay, W.L., Norvell, W.A. (1978). Development of a DTPA Soil Test for Zinc, Iron, Manganese and Copper., Soil Sci. Soc. Amer. J. 42: 421-428.

Lombardo, M., Melati, R.M., Orecchio S. (2001). Assessment of the quality of the air in the city of Palermo through chemical and cell analyses on Pinus needles Atmospheric Environment 35: 6435-6445.
Marschner, H. (1986). Mineral Nutrition of Higher Plants. Institute of Plant Nutrition, Hohenheim Federal. Republic of Germany, Academic Press, London, 1983.

Mattigod, S.V., Page, A.L. (1983). Assesment of metal pollution in soils. Pages 355 - 394 in I. Thornton, Ed. Applied environmental geochemistry. Acedemic Press. London

Önder, S., Dursun, S., Gezgin, S., Demirbaş, A. (2007). Determination of heavy metal pollution in grass and soil of city centre green areas (Konya, Turkey), Polish J. of Environ. Stud.,16(1): 145-154.

Patterson, J.B.E. (1971). Metal toxicities arising from Industry, p.193-207, In Trace Elements, In Soils and Crops. MAFFTechnical Bull., No.21, Her Majestr's Stationery Office, London

Prasad, M.N.V.(1995). Cadmium toxicity and tolerance in vascular plants. Environmental Exp. Bot.35: 525-545

Reeves, R.D., Brooks, R.R. (1983). Hyperaccumulation of lead and zinc by two mettallophytes from a mine area in Central Europe, Environmental Pollution Seri A Ecological and Biological, 31(4): 277-285.

Robert, H.M. (1995). Contaminants in the upper mississippi river: Boston, Butterworth Publishers, 195-230.

Salt, D. (2001). Responses and adaptation of plants to metal stress . 159-179. In; Molecular Analaysis of Plant Adaptations to the Environment Hawkesford MJ (ed.) Kluwer Academic Publishers. Doerdrecht.

Schlichting, E., Blume, H.P. (1966). Bodenkundliches praktikum. Verlag Paul Paney, Hamburg und Berlin, 121-125.

Topbaş, M.T., Brohi, A.R., Karaman, M.R. (1998). Çevre Kirliliği. T.C. Çevre Bakanlığı Yayınları. Ankara.

Yıldız, N. (2001). Toprak kirletici bazı ağır metallerin (Zn, Cu, $\mathrm{Cd}, \mathrm{Pb}, \mathrm{Co}$ ve $\mathrm{Ni}$ ) belirlenmesinde kullanılan yöntemler. Atatürk Üniversitesi Ziraat Fakültesi Dergisi. 32 (2): 207213 